\title{
Cardioprotectant Effect Of Bay Leaf Extract (Syzygiumpolyanthum) On Myocardium Thickness Of Rat Heart
}

\author{
Dian Yuliartha L. ${ }^{1}$, Rizky Trimaulidia ${ }^{2}$ \\ ${ }^{1}$ Department of Anatomical Pathology, Faculty of Medicine, University of Muhammadiyah \\ Malang, J1. Bendungan Sutami No. 188A, Malang 65145, Indonesia, (0341) 551149 \\ Email : lestari@umm.ac.id \\ Receive : Peb25 ${ }^{\text {th }}$ 2021. Revised : May $4^{\text {th }}$ 2021. Published: June $9^{\text {th }} 2021$ \\ DOI : https://doi.org/10.22219/sm.Vol17.SMUMM1.15803
}

\begin{abstract}
High salt diet and prednisone administration will increase blood pressure which chronically causes heart muscle remodeling so that it appears macroscopically as left ventricular hypertrophy. Bay leaf extract contains flavonoids which can lower blood pressure and decrease left ventricular thickening. To determine the effect of bay leaf extract (Syzygiumpolyanthum) on the left ventricle thickening of rat heart (Rattus norvegicus wistar strain) in hypertensive model. True experimental post-test only controls group design with simple random sampling technique. The subjects of this study were 25 male Wistar rats aged 2-3 months weighing 150-200 grams. Rats were induced with prednisone $1.5 \mathrm{mg} / \mathrm{KgBW} /$ day in $2 \% \mathrm{NaCl}$ for 6 weeks followed by administration of bay leaf extract at a dose of $70 \mathrm{mg} / \mathrm{KgBW}$, a dose of $140 \mathrm{mg} / \mathrm{KgBW}$, and a dose of $280 \mathrm{mg} / \mathrm{KgBW}$. Data analyzed by One Way ANOVA, Post Hoc Bonferroni, followed by Linear: One Way ANOVA test showed significant differences between treatments $(p=0.000)$. The Bonferroni Post Hoc test concluded that there were significant differences in the treatment of the P2 and $\mathrm{P} 3$ groups. Linear regression test obtained $\mathrm{R}$ square 0.663 and obtained the equation $\mathrm{Y}=1965.838-1.275 \mathrm{X}$. The extract of bay leaf (Syzygiumpolyanthum) has an effect on decreasing the left ventricle thickening of the white male rat heart (Rattus norvegicus wistar strain) hypertension model.
\end{abstract}

Keyword: Bay Leave Extract, Flavonoid, Hypertension, Thickening of Left Ventricular.

Copyright (C) 2021, Lestari D. Y et al This is an open access article under the CC-BY-SA license

\section{INTRODUCTION}

The national prevalence of hypertension in 2013 reached 25.8\% which is equivalent to 65 million people (Riskesdas, 2013). Untreated hypertension can lead to damage to various organs such as the heart, kidneys, and brain (Singh, Shankar, \& Singh, 2017). The highest prevalence of target heart organ damage is heart failure due to left ventricular hypertrophy (Left Ventricular Hypertrophy $=$ The high prevalence of LVH due to hypertension is a reason for discovering safe treatment with minimal side effects. One of the alternative medicinal methods is by consuming medicinal plants such as bay leaves. 
Bay (Syzygiumpolyanthum) can be impelement as an alternative medicine to treat hypertension because it contains natural antioxidants, called flavonoids (Ismail, et al., 2013). Flavonoids have vasorelaxant effect that can lower blood pressure and heart rate (Ismail \& Wan Ahmad, 2017). In addition, flavonoids also have a cardioprotective effect by suppressing enzymes for the formation of Reactive Oxygen Species (ROS) which play a role in the mechanism of LVH. (Widiasari, 2018)

Until now there has been no research that has examined the effect of bay leaves on LVH, so the result of this study are expected to be used as a basic research on the effects of bay leaves as herbal therapy to protect LVH.

\section{METHODS}

This research used true experimental post-test control group design with simple random sampling technique. The study took place at the Biomedical Laboratory, Campus 2, University of Muhammadiyah Malang. The research period was started from September to December 2019. The population of this study was white male rats, Wistar strain. Samples were taken based on the inclusion criteria of healthy Wistar strain male rats, aged 2-3 months, weighing 150-200g. The sample size is calculated using a formula:

$$
\mathrm{n} \quad=(\mathrm{DF} / \mathrm{k})+1
$$

Notes:

$\mathrm{n} \quad=$ number of subjects per treatment group

$\mathrm{DF}=$ degree of freedom

$\mathrm{k} \quad=$ number of treatment groups

From these calculations, a large range of samples was obtained per treatment group of 3-5 mice.

The controlled variable of this study was the left ventricle thickening of the hypertensive model rats heart and the independent variable was the dose of methanol extract of bay leaves.

The subject of this study was adapted for 1 week and then divided into 5 groups, namely $\mathrm{K}-, \mathrm{K}+, \mathrm{P} 1, \mathrm{P} 2, \mathrm{P} 3$. Group $\mathrm{K}$ - was given only standard food and drink. Groups K +, P1, P2, and P3 were induced with prednisone $1.5 \mathrm{mg} / \mathrm{KgBW} /$ day in $2 \% \mathrm{NaCl}$ solution for 6 weeks. Then the whole group had their blood pressure measured at the end of week 6 . Furthermore, the $\mathrm{K}+$ group was given distilled water for 2 weeks. Group P1 was given bay leaf extract at a dose of 70mg / $\mathrm{KgBW} /$ day, P2 was given bay leaf extract at a dose of 140mg / KgBW / day, and P3 was given bay leaf extract at a dose of $280 \mathrm{mg} / \mathrm{KgBW} /$ day for 2 weeks.

After that the mice were turned off, and their heart organs were taken. Histopathology preparations were made with HE staining. Furthermore, histopathological observations of the left 
ventricle of rat's heart were carried out using a light microscope. The data obtained were then processed by One Way ANOVA test, Bonferroni Post Hoc, and Linear Regression test with SPSS 24 software.

\section{RESULTS AND DISCUSSION}

The results of histopathological observations of the left ventricle of rat heart through a light microscope with a 40x magnification and Optilab software, as well as measuring the thickness of the ventricular wall which was calculated from the lumen to the outer layer with Image Raster software.

The calculations are carried out in 8 different fields of view according to the cardinal directions. The calculation results are expressed in units of $\mu \mathrm{m}$ and then averaged
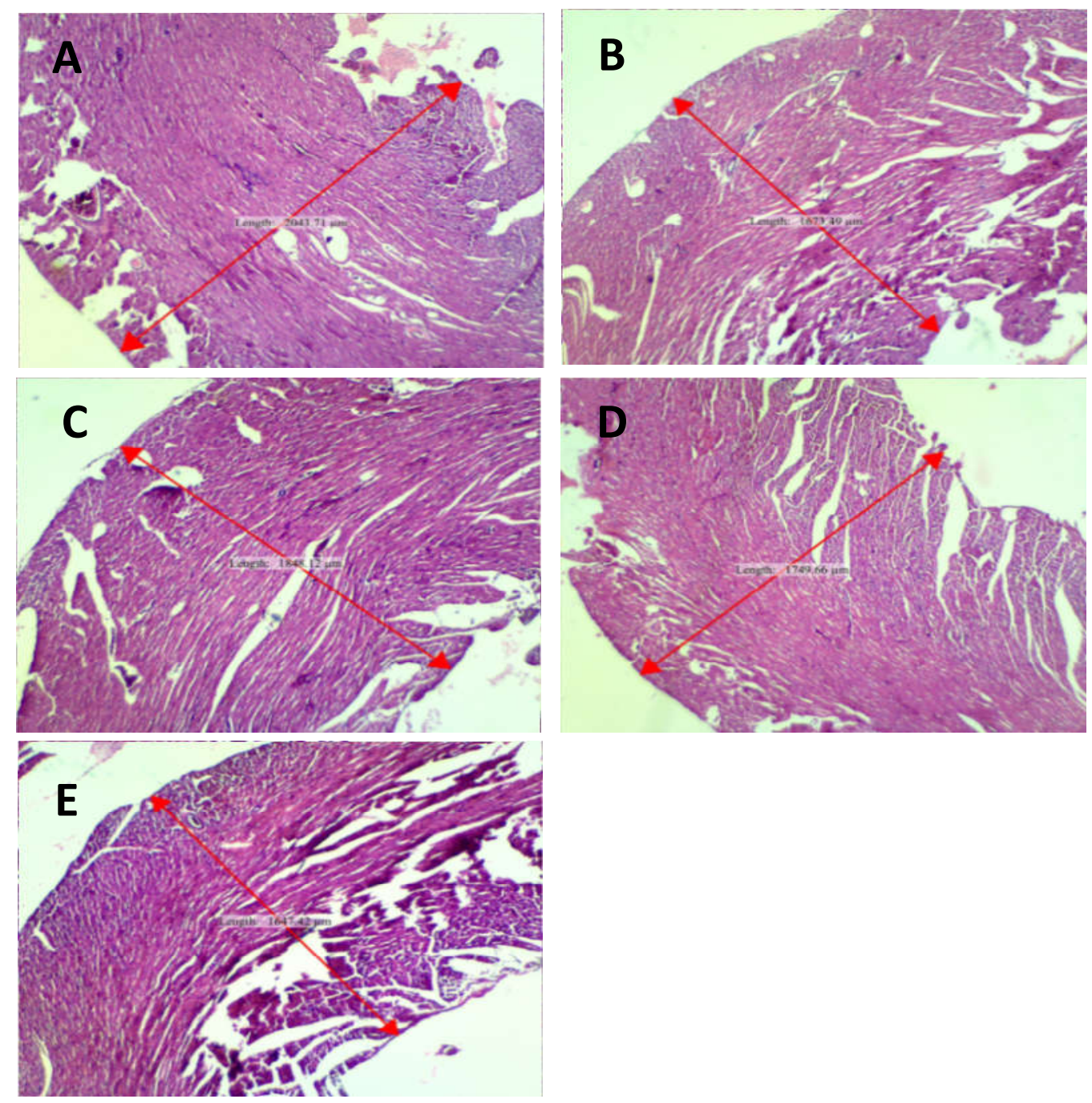

Figure 1. Microscopic measurement of left ventricular wall thickening of the rat heart (A) group K + prednisone- $\mathrm{NaCl}$ induction, (B) group $\mathrm{K}-$, (C) group P1 with bay leaf dose of $70 \mathrm{mg} / \mathrm{KgBW}$, (D) group P2 with bay leaf dose of $140 \mathrm{mg} / \mathrm{KgBW}$, (E) group P3 with bay leaf dose of $280 \mathrm{mg} /$ KgBW. (Sumber data primer, 2020) 
The results of histopathological observations of the left ventricle of rat heart showed that induction of prednisone $1.5 / \mathrm{KgBW} /$ day in $2 \% \mathrm{NaCl}$ solution caused increased systemic blood pressure which chronically could lead to cardiac muscle remodeling so that it would appear macroscopically as myocardial hypertrophy in the left ventricle.

Table 1. Mean Left Ventricular Thickening Results in Rat Heart ( $\mu \mathrm{m})$

\begin{tabular}{ccccccc}
\hline $\begin{array}{c}\text { Treatment } \\
\text { Group }\end{array}$ & 1 & 2 & 3 & 4 & 5 & $\begin{array}{c}\text { Mean } \pm \text { std. } \\
\text { deviation }\end{array}$ \\
\hline K+ & 1894,32 & 1964,48 & 1882,40 & 2259,41 & 2069,31 & $2013,98 \pm 156,03$ \\
K- & 1918,40 & 1613,09 & 1706,31 & 1585,85 & 1592,67 & $1683,26 \pm 140,04$ \\
P1 & 1846,66 & 1819,24 & 1866,89 & 1811,22 & 1782,19 & $1825,24 \pm 32,71$ \\
P2 & 1738,23 & 1725,68 & 1897,47 & 1813,14 & 1665,32 & $1767,97 \pm 89,47$ \\
P3 & 1688,24 & 1675,02 & 1650,20 & 1602,05 & 1540,54 & $1631,21 \pm 60,42$ \\
\hline
\end{tabular}

(Primary data sources, 2020)

From the table, it can be seen that the $\mathrm{K}+$ group induced by $\mathrm{NaCl}$ and prednisone every day for 6 weeks experienced the highest left ventricular wall thickening with an average of 2013.98 $\pm 156.03 \mu \mathrm{m}$. In the P1 group with a bay leaf extract dose of $70 \mathrm{mg} / \mathrm{KgBW} /$ day, it was seen that the thickness of the left ventricle wall of the heart decreased to $1825.24 \pm 32.71 \mu \mathrm{m}$. In the P2 group with a dose of $140 \mathrm{mg} / \mathrm{KgBW} /$ day, the result was a decrease in the thickness of the left ventricle wall of the heart to $1767.97 \pm 89.47 \mu \mathrm{m}$. The most significant decrease in left ventricular wall thickening was shown by the P3 group with an extract dose of $280 \mathrm{mg} / \mathrm{KgBW} /$ day, which was $1631.21 \pm 60.42 \mu \mathrm{m}$, where the value was not much different, even lower than the average in the $\mathrm{K}$ group, which was $1683.26 \pm 140.04 \mu \mathrm{m}$.

Cardiac hypertrophy is a myocardial compensatory response to an increase in heart burden due to high blood pressure over a long period of time. When the body failed to compensate high blood pressure, the heart will experience oxidative stress due to the excessive release of proinflammatory cytokines (especially TNF- $\alpha$ ). Apart from stimulating TNF- $\alpha$, an increase in Reactive Oxygen Species (ROS) levels can also be caused by an increase in angiotensin II in the heart.

In vitro it has been shown that if hypertrophic stimuli such as angiotensin II and TNF- $\alpha$ increase, it will stimulate the production of ROS. Increased levels of ROS lead to an enlargement in the size of the heart myocyte cells leading to cardiac hypertrophy (Hingtgen, et al., 2010).

The results of this study have proven that there was a significant decrease in the thickening of the left ventricular wall of the rat heart that was induced by predinson and $\mathrm{NaCl}$ starting from the P1 treatment group with a dose of $70 \mathrm{mg} / \mathrm{KgBW} /$ day, the P2 treatment group with a dose of $140 \mathrm{mg} / \mathrm{KgBW} /$ day, and the treatment group. P3 at a dose of $280 \mathrm{mg} / \mathrm{KgBW} /$ day. This is 
indicated by the lower mean of left ventricular wall thickening in the P1, P2, and P3 groups compared to the positive control group which was induced only by prednisone and $\mathrm{NaCl}$. The results obtained from the P1 group were the mean reduction in the thickening of the left ventricle of the heart by $1825.24 \pm 32.71 \mu \mathrm{m}$. The mean reduction in left ventricular thickening in group P2 was $1767.97 \pm 89.47 \mu \mathrm{m}$. The result of decreased left ventricular wall thickening of the P3 group was $1631.21 \pm 60.42 \mu \mathrm{m}$, where the value was lower than the average in the $\mathrm{K}$ group, namely $1683.26 \pm 140.04 \mu \mathrm{m}$.

The decrease in left ventricular thickening of the heart which was more significant in the P3 group than in the K-group could occur because one of the mice in the K-group had a high average thickness, which is $1918.40 \mu \mathrm{m}$. This condition can be caused by various endogenous and exogenous factors from the mice themselves. In addition, because the initial condition of the rats' hearts were not examined, they also had the possibility of having abnormalities before the treatment was given.

The administration of bay leaf methanol extract in this study was able to reduce the thickening of the left ventricle of the heart with a significant result, namely p $<0.05$ on the One Way ANOVA test results. In the post hoc bonferroni test, the value was $<0.05$ in the P1, P2, and P3 groups, which means that the dose that showed a therapeutic effect was starting from the P1 dose, which was $70 \mathrm{mg} / \mathrm{KgBW} /$ day..

In this linear regression test, only the $\mathrm{K}+$ group and the P1, P2, P3 positions were included. From the results of the linear regression test, the value $(\mathrm{R} 2=\mathrm{R}$ square) was 0.708 . This means that $70.8 \%$ reduction in left ventricular thickening of the rats' heart is influenced by the bay leaf extract dose, while the rest is expected to be affected by other factors. In this study, a simple linear regression equation was obtained:

$$
\mathrm{Y}=2109,410-92,249 \mathrm{X}
$$

because the regression coefficient (b) is minus (-), it can be concluded that bay leaf extract (X) has a negative effect on the thickening of the left ventricle of the heart $(\mathrm{Y})$. This equation means that each additional $1 \mathrm{mg}$ dose of bay leaf extract will reduce the thickening of the left ventricle of the heart by $92.249 \mu \mathrm{m}$. Meanwhile, if there is no administration of bay leaf extract, the thickening of the left ventricle of the heart is $2109.410 \mu \mathrm{m}$.

Endogenous factors that affect the left ventricle thickening of rat heart is the presence of rat endogenous antioxidants. Endogenous antioxidants possessed by mice include superoxide dismutase (SOD) and glutathione peroxidase (GPx), which protect tissues from oxidative damage caused by ROS such as superoxide (O2- •), hydroxyl radicals $(\mathrm{OH} \bullet$ ), and hydrogen peroxide. (H2O2) (Uzun, et al, 2013). 
Exogenous factors that arise can occur due to stress in mice. This can be triggered when moving the cage, changing the husks, giving the extract through the sonde, and noise (Carlos M, V Baumans, 2009). This stressor can stimulate the hypothalamus to release Corticotropin Releasing Hormone $(\mathrm{CRH})$ which results in the release of Adenocorticotropic Hormone (ACTH) by the anterior pituitary which stimulates the adrenal cortex to release glucocorticoids which will increase the accumulation of glutamate in the synapse and will poison the hippocampus (Taliaz, et al, 2011) . The side effect of glutamate activity is an increase in the activity of $\mathrm{Ca} 2+$ dependent enzymes in excess, resulting in degenerative changes and an increase in free radicals (Arjadi, et al, 2014).

Researchers used the methanol extract of bay leaves to reduce the left ventricle thickening of the heart because in the methanol extract of bay leaves contains flavonoids which can act as antioxidants that can reduce ROS levels by inhibiting the formation of ROS. When the level of ROS in the myocardium decreases, the heart will return from a state of oxidative stress so that the proliferation of myocyte sarcomere will stop. In addition, antioxidants can enhance the function of damaged endothelium so that they are able to produce eNOS (endothelial Nitric Oxide synthase), which is responsible for the production of endogenous vasodilators, NO, so that vasodilation happen. So then, heart load will decrease and sarcomere proliferation can be stopped, then the left ventricle myocardium thickening will be decreased.

This result is in line with previous research that giving various fruit extracts containing flavonoids such as lemon, grape, and chocolate extracts can reduce the interventricular septal wall thickening of the rat heart with hypertension. (Paredes, et al., 2018).

The limitation in this study is that the researchers only observed the presence or absence of changes in the left ventricle thickening of the rats in the histopathological picture. The researchers did not calculate the mass of the heart muscle, observed other histological changes in the heart myocardium, and did not calculate the diameter of the left ventricular chamber, because these three are also indicators of the left ventricle thickening. The researchers were also unable to control the amount of water intake, the amount of feed consumed, and the urine output of rats because these three are endogenous factors that can be confounding.

\section{CONCLUSION}

Based on the results and discussion of this study, the conclusions are as follows there is an effect of bay leaf extract (Syzygiumpolyanthum) on the left ventricle thickening of the white male rats (Rattus norvegicus strain wistar) hypertension model. The bay leaf extract (Syzygiumpolyanthum) dose which began to show an effect on decreasing the left ventricle thickening of the white male rats (Rattus norvegicus strain wistar) hypertension model in this study was $70 \mathrm{mg} / \mathrm{KgBW} /$ day. 


\section{REFERENCES}

Ahmad, A., Sattar, M., Rathore, H., \& Abdulla, M. (2016). Enhanced Expression of Endothelial Nitric Oxide Synthase in The Myocardium Ameliorates The Progression of Left Ventricular Hypertrophy in L-Arginine Treated Wistar-Kyoto Rats. Journal of Physiology and Pharmacology, 31-44.

Bell, K., Twiggs, J., \& Olin, B. R. (2015). Hypertension: The Silent Killer: Updated JNC-8 Guideline Recommendations. Alabama Pharmacy Association , 1-8.

Bisping, E. M. (2014, October). Targeting Cardiac Hypertrophy: Toward a Causal Heart Failure Therapy. Journal Cardiovasc Pharmacol, 64(4), 293-305.

Corvoisier, P. L., Adamy, C., Sambin, L., Crozatier, B., \& Berdeaux, A. (2010). The cardiac reninangiotensin system is responsible for high-salt dietinduced. Eur J Heart Fail., 12(11), 11711178.

Cuspidi, C., Sala, C., Negri, F., Mancia, G., Morganti, A., \& Society, I. (2011). Prevalence of leftventricular hypertrophy in hypertension: an updated review of echocardiographic studies. Nature Publisbing Group, 26(6), 343-9.

Drenjančević-Perić, I., Jelaković, B., Lombard, J. H., Kunert, M. P., Kibel, A., \& Gros, M. (2011). High-salt diet and hypertension: focus on the renin-angiotensin system. Kidney \& blood pressure research.

Goodwin, Julie E., \& David S. Geller. (2012). Glucocorticoid-Induced Hypertension. Pediatric Nephrology, 27, 1059-1066.

Hidayati, M. D., Ersam, T., Shimizu, K., \& Fatmawati, S. (2017). Antioxidant Activity of Syzygium polyanthum Extracts. Indonesian Journal Chemistry, 17(1), 49-53.

Hingtgen, S. D., Li, Z., Kutschke, W., Tian, X., Sharma, R. V., \& Davisson, R. L. (2010). Superoxide scavenging and Akt inhibition in myocardium ameliorate pressure overloadinduced NF-kB activation and cardiac hypertrophy. Physiol Genomics, 41, 127-136.

Hunter, R. W., Ivy, J. R., \& Bailey, M. A. (2014). Glucocorticoids and Renal Na+ transport: Implications for hypertension and salt sensitivity. The Journal of Physiology, 592(8), 1731-1744.

Ismail, A., \& Wan Ahmad, W. (2017). Autonomic receptors and nitric-oxide involvements in mediating vasorelaxation effect induced by Syzygium polyanthum leaves extract. Pharmacognosy Research, 9(5), 9-14.

Ismail, A., Mohamed, M., Sulaiman, S. A., \& Wan Ahmad, W. A. (2013). Autonomic Nervous System Mediates the Hypotensive Effects of Aqueous and Residual Methanolic Extracts of Syzygium polyanthum (Wight) Walp. var. polyanthum Leaves in Anaesthetized Rat. Evidence-Based Complementary and Alternative Medicine : CAM, v.2013(716532).

Kementrian Kesehatan RI. (2014, Mei 17). Hipertensi. Info Datin, pp. 1-7. 
Mitchell, R. N. (2013). Pembuluh Darah. In V. Kumar, A. K. Abbas, J. C. Aster, S. L. Robbins, V. Kumar, A. K. Abbas, \& J. C. Aster (Eds.), Buku Ajar Patologi Robbins (pp. 327-334). Jakarta: EGC.

Paredes, M. D., Romecin, P., Atucha, N. M., O'Valle, F., Castillo, J., Ortiz, M. C., et al. (2018, August). Moderate Effect of Flavonoids on Vascular and Renal Function in Spontaneously Hypertensive Rats. Nutrients, 10(8).

Rahim, E. N., Ismail, A., Omar, M. N., Rahmat, U. N., \& Ahmad, W. A. (2018). GC-MS Analysis of Phytochemical Compounds in Syzygium polyanthum Leaves Extracted using Ultrasound-Assisted Method. Pharmacog J, 10(1), 110-119.

Riskesdas. (2013). Laporan Hasil Riset Kesehatan Dasar (Riskesdas). Jakarta: Badan Litbangkes, Depkes RI.

Sherwood, L. (2014). Pembuluh Darah dan Tekanan Darah. In H. O. Ong, A. A. Mahode, \& D. Ramadhani (Eds.), Fisiologi Manusia: dari Sel ke Sistem (pp. 393-400). Jakarta: EGC.

Shlomai, G., Grassi, G., Grossman, E., \& Mancia, G. (2013). Assessment of Target Organ Damage in the Evaluation and Follow-Up of Hypertensive Patients: Where Do We Stand? The Journal of Clinical Hypertension, 15(10), 742-747.

Singh, S., Shankar, R., \& Singh, G. (2017). Prevalence and Associated Risk Factors of Hypertension: A Cross-Sectional Study in Urban Varanasi. International Journal of Hypertension, v.2017(5491838).

Suryono. (2015). DLBS1033 Reduces Blood Pressure of Hypertensive Wistar-Strain Rats. Folia Medica Indonesiana, 51(3), 168-172.

Tracy, R. E., \& Sander, G. E. (2011). HistologicallyMeasured Cardiomyocyte Hypertrophy Correlates with Body Height as Strongly as with BodyMass Index. Cardiology Research and Practice, 1-9.

Whelton, P. K., Carey, R. M., Aronow, W. S., Casey, D. E., Collins, K. J., Himmelfarb, C. D., et al. (2018). 2017 High Blood Pressure Clinical Practice Guideline. Journal of The American College of Cardiology (JACC), 71(19), e138.

WHO. (2013). A Global Brief on Hypertension. Switzerland: WHO Press.

Widiasari, S. (2018). Mekanisme Inhibisi Angiotensin Converting Enzym oleh Flavonoid pada Hipertensi. Collaborative Medical Journal (CMJ), 1(2), 30-44. 